\title{
1. On the relevance of The General Theory at 80: economic change and economic theory
}

\section{Victoria Chick}

\section{INTRODUCTION}

Most of my colleagues at UCL teach that Keynes's work in general and The General Theory (Keynes 1936) (GT) in particular are irrelevant. The book is, of course, old, so according to the prevailing mainstream mindset, it cannot possibly have anything of value to tell us. A disaffected student was more perceptive: 'If you want new economic thinking, read old books' (Hoang Nguyen).

The question this raises is: what aspects of old books are useful in encouraging new economic thinking, and what do we need to change to fit modern circumstances? My central thesis is that economic theory is always a creature of its time and place, and when the economy evolves, or it is desirable to apply the theory to a different place, theory must be adapted. Some aspects remain and others must be recast. It was this understanding that led Englebert Stockhammer to remark: 'I now see your position: The General Theory is not the end; it is the beginning' (Englebert Stockhammer on my review of his book with Eckhard Hein).

In other words, while it is important to understand what writers of old books were saying, it is not enough just to hark back to these theories and then apply them as if circumstances had not changed. Theory that is relevant to the real world (as opposed to theory that constructs ideal worlds) arises in a particular context and usually takes for granted the institutions and habits of the day or of the recent past. The context, usually tacit, needs to be ferreted out. Once that is done one is free to make decisions about what to retain and what needs to be altered in the light of changes in the economy or differences between economies. From this point of view, economics is profoundly not like physics: atoms have been doing the same things for aeons, but economies evolve, and rather quickly at that.

We need a theory which relates to the economy in which we live if we are 
to frame relevant policy. Keynes scholars have laboured for years over what Keynes said or meant, but the context is still under-explored and with it the matter of whether the context has changed enough to require changes in the theory. It is my purpose here to contribute to this question.

I should emphasise that I am addressing this question at the level of theory, not of method. The methodological foundation of Keynes's theory remains the best in macroeconomics (Chick 2003). The same method, when applied to the analysis of different institutions and behaviours, will yield different theory; for example a theory devised to explain how capitalism works is not applicable to feudalism. I am not dealing here with such a broad institutional change, but the principle is the same.

First I shall simply outline four main contributions of the $G T$ and the institutional and behavioural context from which they arose: Britain in the interwar period. Then I look at each of these contributions in detail, against the background of how the economy has changed, and suggest where Keynes's theory may be obsolescent and what can be kept. Some central propositions of the theory are still valid, and the methodological basis of the GT is even more enduring. This will be our conclusion.

\section{FOUR MAIN THEORETICAL CONTRIBUTIONS OF THE $G T$}

The propositions I wish to examine are the principle of effective demand, the determinants of aggregate demand, the causal priority of investment over saving, and liquidity preference. Others may wish I had chosen differently, but there seems to be fairly widespread consensus that these are important (note I haven't said the important) theoretical innovations of the GT.

\section{The Principle of Effective Demand}

In putting forward the principle of effective demand, Keynes considers 'output-as-a-whole'. Consumption and investment industries are not differentiated. Keynes does this in order to establish the importance of business expectations of demand for their products in the near future when formulating their production strategies and therefore their hiring policies. Actual aggregate demand enters the picture later, when the products go to market; but in the $G T$, where the arrow of time only goes forward, actual demand only influences future output and employment decisions; the production and hiring decisions taken when expectations were formed, whether those expectations later prove right or wrong, are irrevocable.

The principle assumes a decentralised, capitalist production structure: 
no one or no mechanism 'adds up' the employment decisions to see whether there is full employment or not. Thus there is no way labour can insist on full employment. In terms of the 'two Classical postulates' of Chapter 2, firms can always be on their demand curves for labour (given their expectations), but there is no way that labour can insist on full employment, represented by the labour supply curve, which is the locus of full employment positions at every given wage.

This principle is surely still correct. It generalises to the macro level Marshall's derived demand for labour: the primacy of the output decision in determining employment and the illegitimacy of the explanation of employment by means of labour market supply and demand curves on their own.

This institutional context is still in place: it is fundamental to the capitalist mode of production for market sale. Even during significant inflation, for example Britain in the 1970s, when labour tried to negotiate a real wage rather than a money wage, this story held good. For while labour tried to forecast the price level before agreeing to a money wage, they could only project past inflation, while firms had to forecast the level of demand for their products and therefore what prices their output might fetch. A Downing Street intervention to try to get businesses to reveal their price forecasts, or even agree to price declarations, failed.

\section{Aggregate Demand: the Theory of Investment and the Consumption Function}

Moving from effective demand to actual aggregate demand, Keynes invokes the already well-established distinction between consumption and investment. Before the $G T$, economists saw investment as motivated by the current rate of return and conflated this with the rate of interest. Keynes saw that it was the expectations of (time-discounted) profit over the (expected) economic life of the capital equipment (the marginal efficiency of capital, MEC) and, separately, the rate of interest, that determined investment.

Many have argued that there is no empirical relationship between investment and the rate of interest; they have confused Keynes's proposition, which is about the partial derivative, MEC being given, with 'empirical evidence', which can only be about the total derivative, in which any partial relationship with the rate of interest is easily swamped by changes in MEC.

But there are other, perhaps less naive, objections to Keynes's theory of which I will single out two: ${ }^{1}$ first, that Keynes determined the optimal addition to the capital stock but not its rate of change. That ignores the

1 See Chick (1983, pp. 25-9), for other objections and bibliography. 
dependence of the discounted stream of profits on the timing of investment (Chick 1983, pp. 125-8). Second, Kalecki (Targetti and Kinda-Haas 1982) objected that the act of investment changed the parameters on which the decision to invest was taken. This is of course true but ignores the fact that there is no going back on decisions once taken. There is no recontracting in Keynes. Some of the feedback relations that Kalecki outlines are adumbrated in the GT but not fully spelt out, so it cannot be determined how much of the connection between decisions and later profitability was taken into account by Keynes or how much he assumed entrepreneurs factored them in. On one point Kalecki is simply wrong: he says that Keynes based the decision on the current price of investment goods, while Keynes explicitly specified supply price. $^{2}$

On the whole, I would argue that the MEC aspect of Keynes's investment theory goes through to the present day. Some doubt may arise, however, on the question of the rate of interest. Anticipating to a degree the arguments to follow, the role of the rate of interest relates to the financing or opportunity cost of investment. Here Keynes was elliptical, because 'the rate of interest' was something of a moveable feast: the bank lending rate or the rate on long-term debentures? He shifted from one to the other in different contexts. But it has become clear that while investment needs long-term funding, it could be started off by bank lending. And indeed, this double role of initial finance and ultimate funding brings these two rates into play (Chick 1984; Davidson 1986; Bibow 2009, p. 37). We shall see later that bank lending was important to the theory as a whole.

Today, internal finance is the more important source of both finance and funding. In summary, the theory of investment may be subject to revision in the light of this change. We shall return to this point.

Consumption has also seen a change in finance. In the time of the $G T$ there was little credit-finance of consumption; hence the specification of consumption as a function of income alone. In the 1950s and 1960s, hire purchase developed, and later, bank lending for consumption, through credit cards and unsecured loans, began to take off. Banks later turned to mortgages, but credit card debt continued apace. Now the debt-finance of consumption is quite widespread and not regulated as hire purchase was. Under New Labour, this expenditure became the main engine of 'growth' of the economy.

Since Keynes's main purpose was first to alleviate and then to prevent significant unemployment, he was interested in expanding production and employment. Investment played a key role in this $-\mathrm{a}$ role which

2 For the significance of this difference, see Chick (2002). 
debt-finance, especially bank finance, of consumption has called into question. Expansion of the economy was seen at the time as an unalloyed benefit, since there was plenty of scope for useful expansion of the capital stock and most output was useful. The resource content of production was not considered: industry was not seen as pressing significantly on scarce resources. And it was assumed that there was plenty of scope for useful capital accumulation. These assumptions have now radically changed. ${ }^{3}$

\section{Causal Priority of Investment Over Saving}

One of the most innovative results of Keynes's theory is that investment causes saving and not the other way round as the 'classics' taught (and still teach). This reversal of causality rests on bank finance of investment, for banks at the stage of development reached in Britain by the 1870s or so could grant credit quite independently of saving (Keynes [1913] 1973; Chick 1983, ch. 9; and 1986) ${ }^{4}$ and they lent substantially for investment. It is bank finance that gives investment autonomy from saving and current income. Banks no longer lend in any substantial amount to finance investment (now around 6 per cent of their loans; by comparison, Keynes remarked that about 50 per cent of bank assets were industrial as opposed to financial (Keynes [1930a] 1971, p. 311) - not quite the same thing but indicative. Debt-financed consumption has become more important. Thus the investment-saving relationship, and the role of investment as the engine of change in the economy, may have to be reassessed. It is still true, of course, that investment alters productive capacity in a way that consumption does not; it is a moot point whether capital can still be usefully or profitably expanded along traditional lines (Chick and Freeman 2018); green infrastructure is an obvious area for technical change and expansion. ${ }^{5}$

The other feature of bank lending in the GT's time is the general presumption that most bank lending is sound and is paid back. This is embodied in Keynes's 'revolving fund'. The essence of the idea is that investment can continue to be financed with a fairly stable amount of outstanding credit: banks are paid back as the long-term funding for the new capital is secured. What we have seen since the 'liberalisation' of banks began in 1971 with Competition and Credit Control and continued with various acts of deregulation ${ }^{6}$ is that banks have changed their lending preferences

\footnotetext{
3 On the latter point see Chick and Freeman (2018).

4 The importance of bank lending in raising the level of output-as-a-whole is less clear in the $G T$.

5 The British government has not embraced green investment wholeheartedly. See Mazzucato (2013, pp. 124-6).

6 For a comprehensive list see Siniscalchi (2017).
} 
away from investment in productive capacity to property and other assets which can be used as collateral, ${ }^{7}$ with resultant asset-price inflation and no benefit to the economy whatever. They have also, notoriously, increased leverage and engaged in selling complex derivatives, so that the 'real' base of their lending, whether asset values or income streams, becomes almost impossible to trace, and the same real assets or expected income streams 'support' lending of several times their value. The banks are, to all intents and purposes, out of central bank control. This has obvious implications for their stability, as already shown in 2007-08, and for a debt 'overhang' of serious proportions, neither of which Keynes examined, because in his time the banks were very well controlled and well behaved.

\section{Liquidity Preference}

The theory prevailing before Keynes was loanable funds theory, in which the flow of saving was supposed to be equilibrated with the flow of investment by the rate of interest. A moment's thought will show that this idea presumes that all funds saved will go directly into investment. This is implausible when there is a well-developed market in 'seasoned' assets. Saved funds that find their way into those assets provide the assets' previous owners with cash but new funds for investment only to the extent that the assets are sold by firms wanting to invest - normally a small proportion of sales. The loanable funds theory is therefore incompatible with welldeveloped money and capital markets, such as began in England with the foundation of the Bank of England. Those who still hold to this theory (and there are many) are some 400 years out of date.

Liquidity preference overrules the deficient loanable funds theory. Unlike almost the whole of the rest of the $G T$ it deals with stocks of assets, not flows. Financial asset-holders are portrayed as choosing between assets which are relatively capital-safe, such as Treasury bills or other short-term assets, and assets whose capital values vary substantially with changes in the rate of interest. ${ }^{8}$ The rate of interest is viewed not as the reward for waiting but as a reward for parting with liquidity. It is by this means that the rate of interest, now understood as entirely monetary-financial in nature, is established. This seems to me to be entirely applicable to present circumstances, with the addition of consideration of the liquidity preference of the banks (Keynes [1930a] 1971, pp. 59-60; Dow and Dow 1989)

\footnotetext{
7 The Basel capital-adequacy rules encourage this

Keynes formulated liquidity preference in terms of 'money' and other assets, which led to the interpretation that the important distinction was between interest-bearing and noninterest-bearing assets. This has been misleading. See Chick (1991), Chick and Dow (2002).
} 
and firms, though it may need a bit of tweaking to allow for the exceptional elasticity of the money supply that follows from banks' current practices. The fluidity of Keynes's definition of money ${ }^{9}$ and of the rate of interest has caused much trouble but can be sorted out.

\section{Interim Summary}

This section has looked at the institutional and behavioural assumptions that lay behind Keynes's key propositions in The General Theory. They are these:

- A capitalist, industrial economy is producing, on the whole, useful goods.

- There is scope for a productive increase in real capital in traditional industries $\left(\mathrm{K}<\mathrm{K}^{*}\right)$.

- There is little consumer credit $[\mathrm{C}=\mathrm{C}(\mathrm{Y})]$.

- Banks lend to finance investment. Loans are generally paid back. There is no systematic build-up of debt.

- Bank credit is well controlled; the money supply is pretty stable.

- Prices show cycles but no long-term trend.

In addition, though not discussed so far:

- Foreign trade is important but there is no systematic imbalance of payments.

These factors are part of larger macroeconomic trends, which we shall now explore. There will be some unavoidable repetition.

\section{MAJOR MACROECONOMIC TRENDS, STARTING IN THE EARLY 1970S}

\section{The First Big Challenge: Stagflation}

Inflation started to build up after WWII but began to cause concern in the mid-1960s. By the mid-1970s it was a serious problem, and worse, it was combined with unemployment. This was a challenge to Samuelsonian 'Keynesians', who assumed fixed prices, but it was also a problem for

9 Keynes (1936, p. 167, n. 1). 
adherents to $G T$, as 'true inflation' was supposed to kick in only after full capacity of labour or capital was reached. The real culprit in the story was excessive wage claims, validated by accommodating monetary policy in order to keep business afloat.

Keynes did not analyse persistent inflation: the late 19th century had seen prices fall and the interwar period saw first violent fluctuations (analysed in Keynes [1923] 1971) and then falling prices in the Great Depression. But a perceptive reader of $G T$, Chapter 21, could have turned that analysis into a cogent explanation of stagflation by starting with a significant rise in wage demands. Unfortunately, the recovery of the GT from the 'Keynesian' distortions was not sufficiently advanced at the time, and though the defeat of 'Keynesian' theory by stagflation was justified, it took Keynes's theory down with it, quite unnecessarily. A long-term inflationary trend, however, is a problem for the GT: it is not well accounted for. This is not surprising, given the sound banking that on the whole prevailed and the good credit control exercised by the Bank of England at the time.

The changes in the economy that I have mentioned so far became part of larger trends beginning in the 1970s. These are:

- globalisation;

- de-industrialisation;

- privatisation and deregulation;

- 'financialisation', leading to the new banking business model;

- awareness of resource constraints and global warming;

- increased income inequality.

The effect of these factors on the relevance of The General Theory will be briefly examined in the next section, especially the changes in banking. They have taken place in the context of a shift to neoliberalism, which is a challenge not only to Keynes's economics but also to his liberal philosophy.

\section{Globalisation}

As is well known and often deplored, The General Theory deals almost entirely with a closed economy. With the protectionism that prevailed at the time and widespread capital controls (though not yet in Britain) (Bank of England n.d.), the focus fell rather naturally on the national economy. Even in Britain, foreign exchange dealings went exclusively through the Bank of England.

With the relaxation of capital controls after the fall of the Bretton Woods system in 1971, industrial as well as financial capital became footloose: companies were willing to move their operations to other countries if the conditions suited them. In particular they were attracted 
to low-wage countries, thus putting pressure on wage negotiations in high-wage countries. The GT assumptions of a national industrial base and wage negotiations between industry and labour in one country have been undermined by globalisation. However, the wage bargain is not given prominence in $G T$. In the early chapters the wage is taken as given; this assumption is only relaxed in Chapter 19 .

More important is the international nature of the calculations that now underlie a decision to invest. Where will this new investment be located? How will costs, especially wages, be affected by the choice? And where is the demand for the output expected to come from? All these matters are now international for most large firms - and so is the relevant interest rate, given that the globalisation of banking and, at least to some extent, capital markets allows firms to borrow in a range of different countries.

Perhaps a consequence of footloose capital and international wage competition is the deindustrialisation of former industrial powerhouses, particularly Britain and the US. Or is it that the capital stock in those countries is approaching or has even reached its optimum in traditional industries and that they have underinvested in green and high-tech industries (see Chick and Freeman 2018)? The trouble, for not only the GT but almost any current theory of economic growth or employment, is that high-tech industries use very little physical capital and employ rather little labour (Mason 2015; Turner 2016). The robot revolution that is widely predicted will further decouple employment from the making of things and may bring about that problematic leisure that Keynes foresaw in 'Economic possibilities for our grandchildren' (Keynes [1930b] 1972). The question, of course, is who gets the gains, that is, it is a question of distribution.

\section{Privatisation and Deregulation}

Globalisation was promoted by neoclassical economists on the grounds that it improved competition. We all know, don't we, that competition is a Good Thing. And imperfections in markets, such as national boundaries and regulation, are a Bad Thing: they distort the market. The same ultrafree-market thinking led to privatisation and deregulation. This began with the dismantling of the Bretton Woods system in 1971 and, in Britain in the same year, the adoption of Competition and Credit Control. These trends accelerated, along with the takeover by neoliberal thinking, in the days of Thatcher and Reagan. The role of the state in economic affairs was discredited (the state, too, is a 'distortion' in that view). Industrial policy was buried with the sneering remark that the state could not 'pick winners'. Anything the state touched was branded inefficient, and if there was to be any regulation it was to be 'light'. 
Deregulation was promoted in the UK by business itself, of course, though one cannot trace the amounts spent on lobbying as one can in the US. It looks from the outside like regulatory capture, but the case cannot be proved.

Privatisation and deregulation have given private business its head, and it has run away with the freedom it has received. The worst features of capitalism are now much in evidence: hiding price increases in deceptive packaging, passing off horsemeat as beef, mis-selling pensions, insurance and derivatives, fixing LIBOR, offering teaser-rate mortgages - the list is long enough to justify calling the present state of big business predatory capitalism.

By contrast, in 1926 Keynes spoke of many corporations of his day as paying little attention to the profit motive and, though privately owned, seeing themselves as acting in the public interest ([1926] 1972, pp. 288-9). $\mathrm{He}$ attributed this attitude to public corporations but also as a trend to which joint stock companies were approximating, 'when they reached a certain age and size'. Then, 'the shareholders are almost entirely dissociated from the management, with the result that the direct personal interest of the latter in the making of great profit becomes quite secondary', and they concentrate on preserving the stability and reputation of the company. What a gulf separates this system, if Keynes's perceptions were at all accurate, from today's principle of maximising shareholder value by hook or by crook - a principle which the managers have also used to feather their own nests.

Keynes's rosy interpretation did not last long: in 1933 he took a different view: 'The decadent international but individualistic capitalism in the hands of which we found ourselves after the War, is not a success. It is not intelligent, it is not beautiful, it is not just, it is not virtuous, and it doesn't deliver the goods' (Keynes [1933] 1982, p. 239).

There is still a gap - a rather large one I think - between not delivering the goods and engaging in the abusive, even criminal, behaviour toward both customers and the environment that we see all too often today.

\section{Competition, Financialisation and the New Banking Business Model}

Whether as a cause or a consequence of de-industrialisation - or both finance has come to occupy a position of overweening importance in the British economy. Once the critical point was reached when it became easier to earn a high rate of return making money out of money rather than making money out of producing and selling goods, this dominance was assured. 
How did it happen? And what was finance like when Keynes was writing? Does the difference matter for his theory?

The financial system in the UK until 1971 was segmented, highly regulated and compliant. Mortgages were issued by building societies, which insisted on their clients having saved with them for a number of years. Such long commitments were thought unsuitable for banks, whose funding consisted to a large extent of sight deposits. Banks, therefore, lent to finance investment, whether real fixed capital or working and liquid capital. They did not issue much consumer credit. They responded to perceived business risks by altering the proportion of assets devoted to advances and investments (Nevin and Davis 1970): you could describe this choice as their liquidity preference. They always kept very close to the conventional cash reserve and liquid assets ratios of the time. (It would not be profitable to do otherwise.) This meant that, as long as the Bank of England could exercise a high degree of control over both the price and quantity of reserves available to banks, they could control the overall size of banks' balance sheets and thus the rate of creation of new money. ${ }^{10}$

But the banks complained that they were subject to reserve ratios while the building societies were not. J.S. Fforde ([1970] 2015), in the Bank of England, portrayed the banks as being treated as an arm of monetary policy and thought they should be recognised as commercial enterprises. Competition should be encouraged in the financial sector as in the rest of the economy - and Competition and Credit Control was born.

That was only the first step in a long line of deregulatory measures, including the Stock Exchange Big Bang (1986), which allowed retail banks to engage in investment banking. The same agenda was pursued in the US and elsewhere. The result has been a rupture of the former relationship with industry, in which banks served their needs. Banks now concentrate their lending on assets, such as property, and finance has come to dominate economic activity in Britain, while industry has gone abroad. The same tendency is to be found in many countries though perhaps not to the same extent.

The banks forged ahead by increasing their leverage and trading in structured products of dubious quality. The old business model of holding clients' debts to maturity and earning the interest thereon became one of charging fees for initiating loans, repackaging them and selling them on: the 'originate and distribute' business model. They claimed to be redistributing risk, ignoring the fact that they were constructing a web of inter-

10 We have been accustomed to saying that you can control price or quantity but not both. But the Bank did control both; it had enough instruments to do so - Bank rate, open market operations and debt management (see Keynes [1930a] 1971, p. 328). 
related and largely unquantifiable risks. The system crashed in 2007-08, at great expense to the 'real' economy and the public finances. Very little has been done to restore finance to a socially useful industry.

\section{Finite Resources, Global Warming}

Not only has big business become badly behaved toward its customers, it has also plundered the planet's resources. Economic theory deals with this phenomenon under the label of 'market-externalities', a harmless little label that comes into discussion as an afterthought. Our economic system has never asked industry - or consumers - to pay for those externalities: pollution and waste as well as excessive use of resources, many of them irreplaceable. We now know that our activities are causing climate change, and we have become conscious of the scale of externalities as the scale of economic activity has grown. No longer can we view the expansion of the economy as an unalloyed benefit, as Keynes did. Today we have to think, and think hard, about what we produce and how.

Recently, the British Government published a Green Paper (H.M. Government 2017) on industrial strategy. The return of a long-suppressed subject is welcome, and to be fair, there was quite a bit on research and development and financing start-ups, as well as on the regional distribution of industry, but almost the sole focus of the Green Paper was on improving profitability. ${ }^{11}$ There was no discussion of the overuse of resources, of a cleaner, greener economy (apart from some specifics, such as research into improved energy storage), or of truly radical solutions such as the circular economy (Ellen MacArthur Foundation 2013). Nor is there any criterion of public purpose apart from the health of industry's bottom line. Keynes, we know, had much to say about the judgement of public expenditure by means of its financial return, from the 'digging holes' satire in the $G T$ to the accountant's nightmare in 'National self-sufficiency' (Keynes [1933] 1982).

\section{Inequality}

The last chapter of the GT begins thus: 'The outstanding faults of the economic society in which we live are its failure to provide for full employment and its arbitrary and inequitable distribution of wealth and incomes' (GT, p. 372). This is quite startling, for almost nothing is said about income or wealth distribution in the entire book up to this point. (Earlier in the book Keynes mentioned redistributing income to those whose marginal propensity

\footnotetext{
11 Since this paper was written there has been a White Paper (H.M. Government 2018). Its focus on profit is the same.
} 
to consume is greater than average, when wanting to stimulate the economy, but that is about all.) He is mainly concerned with the effect of concentration of wealth on the rate of interest and, famously, expected the rentier aspect of capitalism to 'disappear when it has done its work' (ibid., p. 372).

These days, the richest 1 per cent have found other ways to aggrandise themselves. We must worry about them alongside the stagnation of wages as a potential source of social unrest and about their values and priorities as they find expression in the marketplace. The more markets are expected to rule ungoverned, the more we can expect the 1 per cent to rule the markets, and that is unlikely to turn the world green (except, perhaps, with envy). But apart from obvious causes, like tax breaks, the mechanisms by which the very rich now continue to accumulate are underexplained, despite Piketty's (2013) monumental effort. We need to know why the returns on capital grow faster than GDP and whether the high return to capital is sufficient to explain the skewed distribution of income that we have observed in recent years. The $G T$ is no help here and needs to be supplemented.

\section{CONCLUSION}

Of the four contributions of the GT I have singled out for attention, one emerges from this exploration unaffected by the evolution of the economy: the principle of effective demand. Liquidity preference is also still relevant but needs to be broadened in scope to include the liquidity preference of banks and of firms. Both these groups are sitting on piles of cash since quantitative easing began; this is something Keynes did not envisage. Liquidity preference is not mentioned once in Skidelsky's The Return of the Master (2009), but Nesvetailova (2010) recognises its importance of liquidity illusion in the financial crisis. Asset price inflation and accumulation of debt need also to figure in the story. The theory of investment is still sound but needs to take on board the international dimension of both the competition for markets and wage setting. The causal priority of investment over saving relied on financing by the banks, and investment is now a very minor part of their lending. This proposition needs a re-examination.

More broadly, the optimism regarding economic expansion must now be tempered, both because of resource constraints and because of the culture change within big business. There is a strong case for regulation of their activities. Nowhere is this more evident than in the case of the financial sector, but the regulatory measures that have been proposed so far are more concerned with managing failure (resolution, bailing in) than preventing it. This is the area in which the economic system has moved 
furthest away from the institutional structure that Keynes based his theory on. There needs to be a shift of focus, too, toward the sources and exercise of power, both in analysis of the role of banks and businesses in society and in the matter of income and wealth distribution.

That leaves plenty for us to do to bring Keynes's theory into line with 21 st-century economic structures. We must be careful, however, to preserve the important insights that the $G T$ offers us. Most of all, when revising the theory, we must be sure to retain its methodology, which was streets ahead of its time and is still the best foundation for macroeconomics. Start with the economy as it is; find the relevant simplifications; acknowledge time and uncertainty and the ubiquitous influence of money and finance. Leave the system open to future development and use closure only as a temporary measure.

Although I have argued that there are areas where The General Theory needs to be modified to capture the effects of new structures and behaviour, it is still the best foundation for our search to understand our economy as a whole. It is the beginning, not the end, of that search.

\section{REFERENCES}

Bank of England (n.d.), Website available at http://www.bankofengland.co.uk/ archive/Documents/historicpubs/qb/1967/qb67q3245260.pdf.

Bibow, J. (2009), Keynes on Monetary Policy, Finance and Uncertainty, London: Routledge.

Chick, V. (1983), Macroeconomics after Keynes: A Reconsideration of the General Theory, Cambridge, MA: MIT Press.

Chick, V. (1984), 'Monetary increases and their consequences', in A. Ingham and A. Ulph (eds), Demand, Equilibrium and Trade, London: Macmillan, pp. 237-50.

Chick, V. (1986), 'The evolution of the banking system and the theory of saving, investment and interest', Economies et Sociétés, Cahiers de l'ISMEA, Série 'Monnaie et Production', No. 3, pp. 111-26.

Chick, V. (1991), 'Hicks and Keynes on liquidity preference: A methodological approach', Review of Political Economy, 3 (3), 309-19.

Chick, V. (2002), 'Keynes's theory of investment and necessary compromise', in S.C. Dow and J. Hillard (eds), Keynes, Uncertainty and the Global Economy, vol. 2: Beyond Keynes, Cheltenham, UK and Northampton, MA, USA: Edward Elgar Publishing, pp. 55-68.

Chick, V. (2003), 'Theory, method and mode of thought in Keynes's General Theory', Journal of Economic Methodology, 10 (September), 307-29.

Chick, V. and S.C. Dow (2002), 'Monetary policy with endogenous money and liquidity preference', Journal of Post Keynesian Economics, 24 (4), 587-607.

Chick, V. and A. Freeman (2018), 'The economics of enough', in S.C. Dow, J. Jespersen and G. Tily (eds), Money, Method and Contemporary Post-Keynesian Economics, Cheltenham, UK and Northampton, MA, USA: Edward Elgar Publishing, forthcoming. 
Davidson, P. (1986), 'Finance, funding, saving and investment', Journal of Post Keynesian Economics, 9 (1), 101-10.

Dow, A.C. and S.C. Dow (1989), 'Endogenous money creation and idle balances', in J. Pheby (ed.), New Directions in Post-Keynesian Economics, Aldershot, UK and Brookfield, VT, USA: Edward Elgar Publishing, pp. 147-64.

Ellen MacArthur Foundation (2013), Towards the Circular Economy.

Fforde, J.S. ([1970] 2015), 'Banking system (and credit control)', reprinted as Appendix A in C.A.E. Goodhart, 'Competition and credit control', Financial History Review, 22 (2), 235-46.

H.M. Government (2017), Building our Industrial Strategy (Green Paper), Department of Business, Energy and Industrial Strategy, H.M. Government.

H.M. Government (2017, Building a Britain Fit for the Future (White Paper),), Department of Business, Energy and Industrial Strategy.

Keynes, J.M. ([1913] 1973), 'How far are banks responsible for alternations of crisis and depression?', in The General Theory and After: Preparation, Collected Writings, vol. XIII, London: Macmillan and Cambridge: Cambridge University Press, pp. 2-14.

Keynes, J.M. ([1923] 1971), A Tract on Monetary Reform, Collected Writings, vol. IV, London: Macmillan and Cambridge: Cambridge University Press.

Keynes, J.M. ([1926] 1972), 'The end of laissez-faire', in Essays in Persuasion, Collected Writings, vol. IX, London: Macmillan and Cambridge: Cambridge University Press, pp. 272-94.

Keynes, J.M. ([1930a] 1971), A Treatise on Money, Part II, Collected Writings, vol. VI, London: Macmillan and Cambridge: Cambridge University Press.

Keynes, J.M. ([1930b] 1972), 'Economic possibilities for our grandchildren', in Essays in Persuasion, Collected Writings, vol. IX, London: Macmillan and Cambridge: Cambridge University Press, pp. 321-32.

Keynes, J.M. ([1933] 1982), 'National self-sufficiency', in Activities: World Crises and Policies in Britain and America, 1931-9, Collected Writings, vol. XXI, London: Macmillan and Cambridge: Cambridge University Press, pp. 233-46.

Keynes, J.M. (1936), The General Theory of Employment, Interest and Money, London: Macmillan.

Mason, P. (2015), PostCapitalism: A Guide to our Future, London: Allen Lane.

Mazzucato, M. (2013), The Entrepreneurial State, London: Anthem Press.

Nesvetailova, A. (2010, Financial Alchemy in Crisis: The Great Liquidity Illusion, London: Pluto Press.

Nevin, E. and E.W. Davis (1970), The London Clearing Banks, London: Elek Books.

Piketty, T. (2013), Capital in the 21st Century, trans. A. Goldhammer, Cambridge, MA: Harvard University Press.

Siniscalchi, M. C. (2017), Appendix 1 in A. Vercelli, Crisis and Sustainability, Basingstoke: Palgrave Macmillan.

Skidelsky, R. (2009), Keynes: The Return of the Master, London: Allen Lane.

Targetti, F. and B. Kinda-Haas (1982), 'Kalecki's review of Keynes' General Theory', Australian Economic Papers, 21 (39), December, 244-60.

Turner, A. (2016), 'Economics after the Crisis', Shackle Memorial Lecture, Cambridge: St Edmund's College. 